\title{
Assessment of the uniformity and stability of grapevine cultivars using a set of microsatellite markers
}

M. Dolores Vélez ${ }^{1}$ and Javier Ibáñez ${ }^{2}$

Instituto Madrileño de Investigación y Desarrollo Rural, Agrario y Alimentario (IMIDRA). Finca El Encín. Carretera A-2, PK 38,200. 28800 Alcalá de Henares. Spain.

${ }^{1}$ Present address: Instituto Nacional de Investigación y Tecnología Agraria y Alimentaria (INIA). Dpto. Genética y Ecofisiología Forestal. Carretera A-6, km. 7,5 28040 Madrid.Spain.

${ }^{2}$ Corresponding author. Present address: Instituto de Ciencias de la Vid y del Vino (CSICUR-CAR). Complejo Científico Tecnológico. C/ Madre de Dios 51. 26006 Logroño. Spain. E-mail: javier.ibanez@,icvv.es. Tel. +34 941299694. Fax +34 941299721 


\section{Abstract}

Solidity of microsatellite markers is a key issue for varietal identification, especially when they are used for legal purposes, what includes their probable future use in the distinctness, uniformity and stability testing of new varieties needed for the granting of Plant Breeders' Rights. Nine grapevine microsatellites (VVS2, VVMD5, VVMD27, VVMD28, ssrVrZAG29, ssrVrZAG62, ssrVrZAG67, ssrVrZAG83 and ssrVrZAG112), which had previously demonstrated its capacity to discriminate any grapevine variety, have been assessed to evaluate its uniformity and stability. Nineteen varieties were selected, representative of a high diversity for morphological, agronomical, cultural and historical aspects, as well as for microsatellite allele variability. Then, for each variety, uniformity and stability were evaluated through the analysis of 50 plants from each of three different plots, and five plants from each of seven additional plots. Material from 4,137 plants of 229 plots of the 19 varieties was sampled in seven countries. Of 3,654 plants analyzed with the set of nine microsatellites, 3,299 were of the right variety and used for the survey. An average of 172 individual values was studied for each allele of each microsatellite of each variety, and none differences were detected that could not be explained as technical variations, with the exception of several putative chimeras in two varieties. Of the total of 171 variety x microsatellite combinations, only in one combination ('Merlot' x VVMD27) the number of off-types exceeded the threshold allowed. The remaining 170 combinations have been found uniform and stable according to internationally accepted rules.

Keywords: DUS testing, Plant Breeders' Rights, SSR, UPOV, Varietal identification, Vitis vinifera $\mathrm{L}$.

\section{Introduction}

Many countries, including developing countries and countries in transition to a market economy, are considering the introduction of a system for the protection of new varieties of plants (PVP system). This system seeks to incentive breeding through the granting of Plant Breeders' Rights. Most countries which have already introduced a PVP system have adopted the International Convention for the Protection of New Varieties of Plants (UPOV Convention, www.upov.org/en/publications/conventions/1991/act1991.htm) in order to provide an effective, internationally recognized system (UPOV 2005) within which, more than 81,000 titles were in force at end of 2008 (UPOV 2009). According to this system, a 
candidate variety has to comply with the requirements of novelty, distinctness, uniformity and stability, to be eligible for granting. In the states that are part of the mentioned Act, a technical exam called DUS test (UPOV 2002) is used to determine if the variety is distinct (if it can be clearly distinguished from all the varieties of common knowledge), uniform (if, subject to the variation that may be expected from the particular features of its propagation, it is sufficiently uniform in its relevant characteristics), and stable (if its relevant characteristics remain unchanged after repeated propagation). This DUS testing also forms part of the basis for the registration of new varieties in national lists in many countries.

At the present time, DUS testing is done statutorily using almost exclusively morphology descriptors defined by UPOV (UPOV 2002). Different plants of the candidate variety are compared among them (for uniformity and stability), and also are pair-wise compared with all or a subset of the reference varieties (for distinctness). The growing number of candidate varieties presented every year at each national Plant Variety Protection Office, which also increases the number of varieties in the reference collection, and, in many species, their decreasing genetic variability, makes necessary the adoption of strategies to reduce costs without losing rigour when deciding about the acceptance or rejection of a candidate variety. Furthermore, in the case of many woody species, a number of years are needed before the plants become adult and can be fully described with morphology descriptors (up to 5 years in the case of grapevine, for instance). Thus, it is important to develop more rapid and cost-effective testing procedures to improve the current testing systems, and the use of molecular markers is currently under evaluation. The main issue in DUS testing is to set distinctness, but breeders are also concerned about how the use of molecular markers to establish distinctness would affect the decision on the uniformity and stability of their varieties. In other words, breeders wonder if the use of molecular markers in DUS tests would oblige to an additional effort during the breeding process to keep their varieties uniform and stable not only for the morphological markers but also for these molecular markers. This concern is justified, because microsatellites are among the most used molecular markers in plant species due to their higher mutation rate in relation to the average DNA sequences (Tautz 1989). This characteristic converts microsatellites in highly polymorphic markers, suitable for many applications in plants (Kalia et al. 2011), but makes necessary the verification of their stability for certain applications, especially for 
DUS testing, because UPOV philosophy dictates that any characteristic used to demonstrate distinctness also has to be sufficiently uniform. In addition, this breeders' concern prevents the use of a large number of markers, which would increase the probability of found mutations, and consequently the probability of concluding absence of uniformity and/or stability.

In summary, the aim would be to compile a panel of the smallest number of DNA markers that are enough polymorphic between varieties (and hence useful for distinctness) and also sufficiently uniform within existing varieties. This has to be made on a crop by crop basis, but also on a marker by marker basis, because individual markers may differ in several characteristics, specifically in their uniformity and stability, and thus the conclusions reached for a marker or set of markers cannot be valid for another marker or set (Cooke et al. 2003). This is true to such an extent that, in grapevine, different authors have proposed different sets of microsatellite markers for studying clonal variation because of their high intra-varietal variability (Pelsy et al. 2010; Regner et al. 2006).

Grapevine is one of the oldest cultures in the world. Their plants are woody, and asexually multiplied through cuttings. There are many varieties in the world (between 5,000 and 10,000) and many of them have been cultured for several centuries (This et al. 2006), what obviously favour the existence of clonal variation. In fact, many grapevine varieties are considered to consist of a population of clones descended by vegetative propagation from a single plant, and where different types of mutations are responsible for genetic variation among clones (Pelsy 2010). In addition to these traditional varieties, there is an increasing number of new varieties released to the market every year, especially producing table grapes. This large number of existing varieties, their long and wide culture and the difficulties for performing good morphological descriptions gave place to certain confusion in the viticulture world, which molecular markers are contributing to resolve. Among them, microsatellite markers have been extensively used in grapevine for different purposes including variety identification in collections, pedigree analysis, or genetic mapping (Sefc et al. 2009). But this type of markers have also been used aiming to distinguish clones produced by intra-varietal diversity, with different degree of success (Baneh et al. 2009; Crespan 2004; Cretazzo et al. 2010; Gonzalez Techera et al. 2004; Imazio et al. 2002; Moncada et al. 2006; Pelsy et al. 2010; Regner et al. 2000a; Regner et 
al. 2000b; Riaz et al. 2002). These studies confirmed the necessity of evaluate individually each marker for stability.

A considerable effort has been made at IMIDRA to evaluate a set of nine selected microsatellites for legal applications in grapevine. The possibility of establishing distinctness through the use of that set of microsatellite markers has been already studied (Ibáñez et al. 2009b). In that study, the set of nine microsatellites was used to genotype 991 grapevine accessions that finally resulted in 489 different genotypes. Average values for number of alleles per locus (19), Polymorphic Information Content (0.764) and heterozygosities observed (0.773) and expected (0.785) indicated the high level of polymorphism existing in grapevine for these markers. The maximum intra-variety distance found (measured in number of different alleles) was one allele between two accessions of the same variety, after 3,171 pair-wise comparisons, while the closest different varieties differed in two alleles, and it was only 1 case of 119,316 pair-wise comparisons. The average pair-wise distance found among the 489 non-redundant varieties was 12.4 alleles, a $69 \%$ of the maximum possible distance (18 alleles for the 9 microsatellites). In summary, this previous study demonstrated that the set of 9 markers was powerful enough to discriminate and identify any grapevine variety. The aim of the present work was to assess the uniformity and stability of grapevine for the same nine microsatellites through the study of more than 3,000 plants of 19 varieties.

\section{Material and Methods}

\section{Plant material}

Plant material consisted in young leaves from plants of 19 grapevine varieties with diverse characteristics (Table 1): 'Cardinal', 'Crimson Seedless', 'Flame Seedless', 'Imperial Napoleón', 'Italia', 'Ohanes', 'Red Globe', 'Sugraone', and 'Sultanina' (table grapes), 'Airén', 'Cabernet Sauvignon', 'Chardonnay', 'Garnacha', 'Merlot', 'Monastrell', 'Palomino Fino', 'Sauvignon Blanc' and 'Tempranillo' (wine grapes), and 'Muscat of Alexandria' (wine and table grapes). The experimental design included the analysis of 50 plants of each of 3 plots for the survey of uniformity (U-plots) and 5 plants of 7 additional plots for the survey of stability (S-plots). When possible, 2 extra plants per plot were sampled. For the sampling out of Spain, material was requested to different collections and research centres (see acknowledgements). In Spain, generally the sampled plants were in 
commercially exploited plots. Table grape samples were taken in the South and East of the Iberian Peninsula, where this material is cultivated. Wine grapes are cultivated throughout the country, and support was requested to research centres and, especially, to 28 Regulator Councils of wine Origin Denominations: Almansa, Calatayud, Campo de Borja, Cariñena, Tarragona, Condado de Huelva, Costers del Segre, Jerez, Jumilla, La Mancha, Méntrida, Monterrei, Montilla-Moriles, Navarra, Penedés, Ribeira Sacra, Ribeiro, Ribera de Duero, Ribera del Guadiana, Rueda, Rioja, Málaga, Utiel-Requena, Valdeorras, Valdepeñas, Valencia, Vinos de Madrid and Yecla. Personnel of these Councils selected the plots and, in many cases, assisted us to take the samples.

Information about the plots was also requested, specifically the year of planting of the plot, although not always could be provided.

\section{Microsatellite analysis}

DNA extractions were done using commercial kits: DNeasy Plant Mini kit or DNeasy 96 Plant Kit (Qiagen). Nine previously described nuclear microsatellite loci were used: VVMD5 (Bowers et al. 1996); VVMD27 and VVMD28 (Bowers et al. 1999); VVS2 (Thomas and Scott 1993); ssrVrZAG29, ssrVrZAG62, ssrVrZAG67, ssrVrZAG83 and ssrVrZAG1 12 (Sefc et al. 1999). A multiplex PCR with the nine markers was used, and simplex PCRs were done when necessary. One primer of each pair was fluorescently labelled with Dye Phosphoramidites (6-FAM, HEX or TET). The separation of fragments and data analysis was carried out in an ABI PRISM 310, using TAMRA 500 as an internal marker and GeneScan ${ }^{\circledR}$ software (Applied Biosystems, Foster City, CA) to size the fragments. PCR and electrophoresis were done according to (Ibáñez et al. 2009a).

\section{Evaluation of Uniformity and Stability}

Uniformity and stability have to be determined for each variety and each marker individually. Then, conclusions about each single marker are reached through the evaluation of its behaviour in all the varieties studied. It is not possible to distinguish between uniformity and stability in a vegetatively propagated crop, and more especially in grapevine, where many present varieties have been cultivated for centuries. Even for new varieties the two concepts overlap: For instance, the European Community Plant Variety Office (CPVO) states in their Protocol for Distinctness, Uniformity and Stability Tests in Grapevine: 'A candidate will be considered to be sufficiently stable when there is no 
evidence to indicate that it lacks uniformity'. Anyway, the experimental design in this work tried to include some differences: the uniformity survey included, for each variety, the analysis of 50 plants of each of 3 plots, designated U-plots (150 plants). It is assumed that most of the plants in a plot are approximately in the same cycle of vegetative reproduction. For the stability survey, the design included the analysis of 5 plants of each of 7 plots, designated S-plots (35 additional plants). It is assumed that different plots probably would include plants in different cycles of vegetative reproduction, especially if the plots were planted in very different years and locations. Given that the grapevine varieties are clones, if they are uniform and stable for the microsatellites used, one expects to obtain the same alleles for each microsatellite in each of the analyzed plants, independently of their origin. Uniformity and stability were studied through the analyses of the raw data produced after the electrophoresis of the amplified microsatellite DNA fragments in an ABI PRISM 310 genetic analyzer. GeneScan ${ }^{\circledR}$ software completely automates the entire process of baselining, peak detection, and peak sizing of DNA fragments. Using an internal-lane size standard that is co-electrophoresed with each sample, GeneScan ${ }^{\circledR}$ software automatically sizes the PCR products and normalizes the differences in electrophoretic mobility between injections. Although these data correspond to the sizes in base pairs (bp) of the fragments under analysis, they are not expressed as integer numbers, as expected, because the size is calculated from a lineal regression based on the size standard (Local southern method). The result is that the peak sizes are expressed as numbers with two decimals, and for the same allele, slightly different raw values can be obtained. In a conventional genotyping procedure, these raw values are transformed through an allele binning process, obtaining for every variety a genotype with (normally) two integer numbers corresponding to the allele sizes in bp. Because the uniformity and stability are being evaluated, the differences between the raw values obtained for each allele were directly analyzed and compared, instead of applying an allele binning process and comparing the bins. Specifically, the difference between the maximum and minimum raw values was established for each allele of each microsatellite in each variety ('extreme' differences), and those cases where this difference was larger than 1 bp were carefully re-analyzed (all the nine microsatellites have a di-nucleotide motif). This re-analysis consisted in the selection of the DNAs that presented the extreme values and their amplification in the same conditions. Additionally, 
in some cases these DNAs were also amplified with Pyrobest DNA Polymerase (Takara), which possesses an associated $3^{\prime} \rightarrow 5^{\prime}$ exonuclease (proofreading) activity.

\section{Results}

\section{Sampling and microsatellite analysis}

Material from 4,137 plants of 229 plots of 19 varieties was collected in 7 countries along three years (Table 2). The largest number of samples was taken in Spain (3,580 plants, 170 plots), followed by South Africa (258 plants, 15 plots), Chile (107 plants, 9 plots) and USA (90 plants, 18 plots). At least 10 plots were analyzed per variety, although in 'Flame Seedless' and 'Sultanina' only one complete and one incomplete U-plots could be sampled, instead of the planned 3 U-plots.

The approximate year of planting could be obtained for 186 of the 229 plots sampled. In 14 varieties, the range of planting of the sampled plots was larger than 40 years (Table 2). A special mention should be done for the 18 plants sampled from the Royal Botanic Garden of Madrid (14 'Garnacha', 2 'Imperial Napoleón', 1 'Monastrell' and 1 'Sultanina') because these vines were planted ca. 1800 .

When possible, sampling was done in excess, and about $12 \%$ of the plants sampled were not analyzed, either because there were more than 50 plants sampled in a U-plot or more than five plants in an S-plot, or more than 10 plots of a variety. In total, 3,654 samples were analyzed with the set of nine microsatellites. Table 3 shows the genotypes found for the 19 varieties.

The molecular analysis showed that some or all the plants of some plots did not correspond with the variety, because differed from the expected genotype in several microsatellites. Thirteen U-plots (five complete) and seven S-plots (five complete), accounting for a total of 355 plants, were considered mistaken (Table 2). The variety with the larger number of mistakes was 'Muscat of Alexandria', with 108 wrong plants from five plots, followed by 'Palomino Fino', with 64 wrong vines from four plots.

On the other side, none wrong plant was detected in 9 of the 19 varieties. A total of 3,299 analyzed plants were considered correct regarding their identity. Supplementary Table S1 includes the total number of plots and plants subjected to microsatellite analysis for each variety, as well as the number of correct plants. The total number of plants analyzed for each microsatellite ranged from 3,211 to 3,287, with an overall average of 3,262. Within a 
variety, the range of plants studied varied between 110 for some microsatellites in 'Flame Seedless' to 200 for most of the microsatellites in 'Crimson Seedless'. The average value was 172 plants per microsatellite and variety.

\section{Evaluation of uniformity and stability}

Uniformity and stability of the grapevine varieties for the nine microsatellite markers was surveyed through the analysis of the raw values obtained for each allele in all the plants of each variety. A database with 51,141 individual raw values was analyzed. Table 4 shows the extreme differences found for each allele and variety, corresponding to the subtraction between the maximum and minimum values. The global average extreme difference was 0.71, but it varied between microsatellites: ssrVrZAG83 and ssrVrZAG67 presented the lowest values (0.47 and 0.51 respectively), while VVMD5, VVMD28 and ssrVrZAG29 presented values above 0.8 . The extreme differences also varied between varieties. 'Sugraone' presented the lowest average value, (0.54), followed by 'Airén' and 'Ohanes' (0.58), while Cabernet sauvignon and Red Globe presented the highest average value (0.92). Globally, in 289 of the 298 allele x variety combinations studied (97\%), the extreme differences found were equal or below $1 \mathrm{bp}$.

Extreme differences above $1 \mathrm{bp}$ were found in nine allele $\mathrm{x}$ variety combinations, involving, three of the nineteen varieties and three of the nine microsatellites: VVMD5 and VVS2 in 'Cabernet Sauvignon' and 'Red Globe', and VVMD28 in 'Red Globe' and 'Sultanina' (Table 4). Seven of these nine allele x variety combinations presented extreme differences lower than $1.5 \mathrm{bp}$, and all were lower than $2 \mathrm{bp}$. The DNAs involved in these high extreme differences were further studied. In a second amplification in the same experimental conditions the differences were reduced below 0.20 in all the cases (Table 5). An additional amplification of 'Cabernet Sauvignon' DNAs with a proof-reading polymerase corroborated the absence of differences above $1 \mathrm{bp}$.

Grapevine is a diploid species, and thus one or two allelic peaks are expected for every microsatellite. Nevertheless, among the 3,299 analyzed samples there were 51 that presented three alleles (peaks) for one microsatellite: 49 of the 189 plants of 'Merlot' presented three alleles for the locus VVMD27, and two of the 191 plants of 'Cardinal' showed three alleles for the locus VVMD5 (Figure 1). The two anomalous plants of 'Cardinal' were from the same plot, while in the case of 'Merlot', there were seven plots affected, four of them only partially (some plants were normal and some anomalous). The 
analysis of some of these samples was repeated individually for the implied microsatellite with the same DNA and with an independently extracted DNA, to ensure there was not a DNA contamination. The results obtained were exactly the same: three alleles in VVMD27 ('Merlot') and VVMD5 ('Cardinal'). Besides, the microsatellite locus ssrVrZAG47 (Sefc et al. 1999) was analyzed in some of the anomalous plants of 'Merlot'. This microsatellite is the same locus than VVMD27, but with a different primer design that makes ssrVrZAG47 alleles about 20 bp shorter than those of VVMD27 (Dalbó et al. 2000). Again, the three-allele status appeared for the anomalous plants in the microsatellite ssrVrZAG47 (Figure 1).

\section{Discussion}

In this work the uniformity and stability of grapevine varieties for a set of nine microsatellite markers have been surveyed. These nine markers were selected for numerous reasons (Ibáñez et al. 2009b) including that they are publicly available, distributed in different linkage groups, highly polymorphic (except ssrVrZAG29), able for multiplexing in one PCR, and widely use, especially four of the markers included as descriptors by the Organisation Internationale de la Vigne et du Vin (OIV 2007). Above all, this set of markers was able to discriminate any grapevine variety of a collection of 991 accessions (except those originated through somatic mutations) beyond any doubt, and showed a very low total probability of identity: $6.93 \cdot 10^{-12}$ (Ibáñez et al. 2009b).

\section{Plant material to evaluate uniformity and stability}

The study relied on the analysis of 19 varieties that are considered uniform and stable regarding their morphology, and most of them have been approved for cultivation in different countries through a DUS test. Nevertheless, there are thousands of varieties existing in grapevine (This et al. 2006), and a previous work on wheat and tomato showed that the degree of non-uniformity detected could be dependent on the sample of varieties studied (Cooke et al. 2003). So, the selected varieties had to be representative of the existing diversity, and for that they were chosen to incorporate diversity for numerous factors, including the use of the grapes (wine and table), their temporal origin (ancient and more recent) and their geographical origin (from different continents). The selected varieties also differ for important traits presently recommended by the UPOV for grouping grapevine varieties for DUS testing (UPOV 2008b) like the colour of the skin of the berry, the presence or absence of seeds and the time of ripening (Table 1). Other aspects like their 
cultivation extension and trans-national cultivation were also considered: for instance, 'Airen' is the variety with the most cultivated area in the world, although it is only planted in Spain, while, on the other side, varieties like 'Sultanina', 'Cabernet Sauvignon' or 'Muscat of Alexandria' are cultivated in many countries throughout the world (Galet 2000).

Besides considering the diversity present in the 19 varieties for morphological, agronomical or cultural aspects, the representativeness of the selected varieties was evaluated for the microsatellite allele variability, using as a reference a database of 489 non-redundant genotypes. This database was built for the evaluation of distinctness (Ibáñez et al. 2009b), and includes a high number of the most cultivated grapevine varieties in the world (Galet 2000), as well as some rootstock varieties, species of non-vinifera Vitis genus and genus of Vitaceae family. To determine if the selection of 19 varieties was representative regarding their microsatellite alleles, the presence in the selected varieties of the most frequent alleles found in the collection of 489 non-redundant genotypes was studied (Supplementary Table S2). All the alleles of the collection with a frequency above 0.04 were present in the 19 selected varieties. On average, and considering the nine microsatellites, $34 \%$ of all the alleles are present in the selected varieties. This low value is due to the presence of rare alleles, including those provided by non-Vitis vinifera varieties, in the collection used. More importantly, the sum of the allelic frequencies of the alleles that appeared in the 19 selected varieties represents an average of $91.8 \%$ of the total, with extreme values of $85.9 \%$ for VVMD28 and $95.3 \%$ for VVMD27. These results indicate that the 19 selected varieties are highly representative of the diversity existing in grapevine species.

As far as we know, the large sampling around the world done in this work (4,137 plants) is one of the most important ever done in grapevine for DNA analyses. These analyses also allowed to determine that almost $10 \%$ of the sampled plants showed a genotype that did not match with the expected one for the corresponding variety, despite the, generally, careful selection of the material sources. This is not uncommon in viticulture, although it is a high percentage of mistakes. Pelsy et al. (2010) found in a recent study that 10 out of 344 (3\%) accessions of seven varieties of certified clones and introductions preserved in French repositories were either self-progeny, possible offspring of the expected variety or misclassified varieties. 
In conclusion, the large number of correct plants (between 112 and 200) of a significant number of representative varieties (19) constitutes a very suitable material to evaluate the uniformity and stability of any molecular marker in the grapevine species. In this case, the material has been used to study a set of nine microsatellites that had already proved useful for the characterization of grapevine varieties and the establishment of distinctness.

\section{Evaluation of uniformity and stability}

In this work, the assessment of uniformity was planned through the study of 50 plants of 3 different plots of each of the 19 varieties with the set of nine microsatellites. Because grapevine is a woody plant, a controlled study of stability, through multiplying plants of all the varieties, would be difficult and unpractical, and would allow studying only one, or a very limited number of cycles of multiplication. In fact, UPOV states that it is not usual to perform tests of stability in grapevine but, where appropriate, or in cases of doubt, stability may be tested, either by growing a further generation, or by testing a new plant stock to ensure that it exhibits the same characteristics as those shown by the previous material supplied (UPOV 2008b). For this reason, and considering that the same varieties are multiplied in different places, producing plants that are certainly in very different cycles of multiplication, we decided to study stability looking at plants of plots from different origins, and when possible, of different age. So, the evaluation of stability was planned through the study of 5 plants of 10 different plots (including the 3 studied for uniformity) of each of the 19 varieties with the set of nine microsatellites. The approach required either diverse origins of the material or a wide range of ages for the different plots studied. In most cases both requirements were fulfilled. Plant material studied came from at least two different countries in 12 of the 19 varieties, and in 8 varieties it came from at least 4 different countries (Table 2). In the 6 varieties for which only Spanish material could be obtained, the range of differences between the youngest and the oldest plot was between 46 and 199 years. The only exception was Red Globe, for which only recently planted Spanish plots could be sampled (Table 2) but, even in this case, the less restrictive conditions required by UPOV mentioned above were fulfilled. The diverse origins of the material as well as the wide range for the plot planting year allow reasonably concluding that the material studied is suitable for the evaluation of the stability.

On average, 172 individual raw values were studied for each allele of each microsatellite of each variety. After the first analysis of these raw values, $97.3 \%$ of the alleles presented 
extreme differences below $1 \mathrm{bp}$, and were directly considered experimental variation, given that the basic unit of repetition for these microsatellites is $2 \mathrm{bp}$. The second analysis of the nine alleles where differences larger than $1 \mathrm{bp}$ were found was definitive, as differences disappeared in all the re-studied cases, either with the same procedure or, additionally, with a proof-reading polymerase and a specific protocol.

So, in this study we have not detected differences that could not be explained as technical variations, with the exception of the samples that presented three alleles (peaks) in 'Merlot' (VVMD27), and 'Cardinal' (VVMD5). This three-allele status could be due to periclinal chimerism, a phenomena previously described in grapevine (Bertsch et al. 2005; Crespan 2004; Franks et al. 2002; Moncada et al. 2006). In grapevine, the shoot apical meristem is considered to be composed of only two (L1 and L2) distinct cell layers (Thompson and Olmo 1963). The most-likely interpretation of the presence of three microsatellite alleles per locus is that one of the two (diploid) alleles has mutated. Through vegetative propagation, this mutation has been maintained in one of the distinct cell layers of the apical meristem while the original genotype is maintained in the other cell layer of the plant. These chimerical states seem to be the way through diversification within grapevine varieties goes (Hocquigny et al. 2004; Pelsy 2010). Anyway, the case of Merlot is uncommon. A high number of plants from different plots presented the tri-allelic state for VVMD27, and in a considerable number of plots only some plants were anomalous. We did not have the opportunity to evaluate the anomalous plants morphologically, as to establish any relationship between microsatellite and morphological uniformity or stability. With that aim we took samples of another 50 plants at random from a plot of 'Merlot' at Finca El Encín and tagged the plants, but none of them presented the tri-allelic genotype (data not shown).

In vegetatively propagated crops no major differences exist between uniformity and stability, and experience has demonstrated that when a variety has been shown to be uniform, it can also be considered to be stable (UPOV 2008b). Regarding the type of analysis done here, if the microsatellite analysis method is reliable, absence of uniformity and/or stability is only expected when a mutation occurs. In the grapevine, especially for the long time of cultivation of many varieties this fact has been reported several times. (Regner et al. 2000b) used 40 microsatellite markers, including the nine studied here, to search for variability among 10 clones of grapevine variety 'White Riesling' and found 
polymorphism for 5 markers, but none of them was among those under evaluation in this work. That has been the general rule in the works published until now (Gonzalez Techera et al. 2004; Ibáñez et al. 2000; Imazio et al. 2002; Regner et al. 2000a; Vargas et al. 2007; Zulini et al. 2005), with the exception of chimeras found for VVS2 in 'Pinot' (Franks et al. 2002; Hocquigny et al. 2004), and in 'Greco di Tufo' (Crespan 2004) and for ssrVrZAG67 in 'Cabernet sauvignon' (Moncada et al. 2006) that we did not observed in this work. In a recent and extensive work 334 accessions of 7 grapevine varieties were studied using up to 34 microsatellite markers, including 6 used here (Pelsy et al. 2010). Intra-varietal variability was found for 15 markers, including VVMD27 in the variety 'Savagnin' and again VVS2 in 'Pinot' and other three varieties: 'Cabernet Franc', 'Riesling' and 'Savagnin'. None clonal variation was found for the remaining four common markers used: ssrVrZAG62, ssrVrZAG67, VVMD5 and VVMD28. In comparison, four of the six markers of the OIV set were affected by clonal variation: VVMD7 and ssrVrZAG79 in addition to the mentioned VVS2 and VVMD27.

UPOV establishes that, for vegetatively propagated and self-pollinated varieties, it is possible to assess uniformity by the number of obviously different plants ('off-types') that occur (UPOV 2008a), while in the Guidelines for the conduct of tests for distinctness, uniformity and stability in grapevine (Vitis L.)(UPOV 2008b) indicates that 'For the assessment of uniformity, a population standard of $1 \%$ and an acceptance probability of at least $95 \%$ should be applied. In the case of a sample size of 5 plants, no off-types are allowed'. In asexually propagated crops, if the microsatellite analysis method is reliable, off-types are only expected when a mutation occurs. In this study, 19 varieties have been analyzed with nine microsatellites. Of the total of 171 variety $\mathrm{x}$ microsatellite combinations, 170 have been found uniform according to UPOV guidelines, while only in one combination ('Merlot' $x$ VVMD27) the number of off-types exceeded the threshold allowed.

The study and results presented here have implications not only for Plant Variety Protection, nor for grapevine, but for the perception of microsatellite markers stability in other crops. The high polymorphism existing for many of these markers is commonly perceived as a risk for stability. Nevertheless, this work shows that it is possible to find very polymorphic microsatellite markers which, at the same time, have proven stable, after 
analyzing plants from varieties cultivated for more than 2000 years, and spread worldwide for many centuries.

\section{Conclusions}

The global study is, as far as we know, the most complete study ever done in plants with the purpose of testing the stability and uniformity of varieties for microsatellite markers. Microsatellite genotypes in the samples have been found consistent with the expected genotype in $99 \%$ of the variety $\mathrm{x}$ microsatellite combinations studied, what allow concluding that grapevine varieties are uniform and stable for the nine microsatellites used. Consequently, the use of this system of microsatellite analysis would not require any additional effort by grapevine breeders to keep uniformity and stability in their new varieties. In view of its large genetic discrimination capacity (Ibáñez et al. 2009b) and its uniformity and stability (present work) this set of nine markers has proven very useful for variety identification issues in grapevine, especially those with legal implications. Until now, no microsatellite marker has been approved by UPOV for DUS tests in any species, but this set of nine markers has contributed to characterize the grapevine reference collection used for DUS testing by the Spanish Plant Variety Office.

\section{Acknowledgements}

This work was financially supported by the project VIN01-025 (Instituto Nacional de Investigación y Tecnología Agraria y Alimentaria, Agriculture Ministry of Spain). M.D. Vélez was funded by a pre-doctoral fellowship from the Instituto Madrileño de Investigación y Desarrollo Rural, Agrario y Alimentario (IMIDRA). The large sampling needed in this work has been possible thanks to the collaboration of numerous people and public and private institutions, in Spain and abroad. We are grateful to all of them.

Specifically, plant material from wine varieties was obtained thanks to the collaboration of numerous Regulator Councils of wine Origin Denominations (see Material and Methods). Among the people who personally contributed to the sampling are: José María Hurtado (Superior Frutícola S.A., Murcia, Spain); Edit Hajdu (FVM Szölészeti és Borászati Kutató Intézete, Hungary); Patricio Hinrichsen (Centro experimental La Platina-INIA, Chile); Tim Sheehan (Sheehan Genetics, USA); Jean Satterwhite (National Clonal Germoplasm Repository for Nut Crops, USA); Erika Maul (Institute for Grapevine Breeding, Germany); Jorge Zerolo (Agrovolcán, Tenerife, Spain); Nuria Cid (Estación de Viticultura y Enología de Galicia, Orense, Spain); Peter Allderman (Top Fruit, RSA); Thierry Lacombe (DGPC- 
Diversité et Génomes des Plantes Cultivées, France); Miguel Lara (CIFA-Centro de Investigación y Formación Agraria, Jerez de la Frontera, Spain); Joaquín Borrego, Paz Fernández, Maite de Andrés, Carlos González, Alba Vargas, Gregorio Muñoz, Cristina Rubio and Mariano Cabellos (IMIDRA, Spain). We apologize for any non-deliberate omission in this list.

\section{References}

Baneh HD, Mohammadi SA, Mahmoudzadeh H, de Mattia F, Labra M (2009) Analysis of SSR and AFLP Markers to Detect Genetic Diversity Among Selected Clones of Grapevine (Vitis vinifera L.) cv. Keshmeshi. S Afr J Enol Vitic 30 (1):38-42

Bertsch C, Kieffer F, Maillot P, Farine S, Butterlin G, Merdinoglu D, Walter B (2005) Genetic chimerism of Vitis vinifera cv. Chardonnay 96 is maintained through organogenesis but not somatic embryogenesis. BMC Plant Biol 5 (20)

Bowers JE, Dangl GS, Meredith CP (1999) Development and characterization of additional microsatellite DNA markers for grape. Am J Enol Vitic 50 (3):243-246

Bowers JE, Dangl GS, Vignani R, Meredith CP (1996) Isolation and characterization of new polymorphic simple sequence repeat loci in grape (Vitis vinifera L.). Genome 39:628-633

Cooke RJ, Bredemeijer GMM, Ganal MW, Peeters R, Isaac P, Rendell S, Jackson J, Roder MS, Korzun V, Wendehake K, Areshchenkova T, Dijcks M, Laborie D, Bertrand L, Vosman B (2003) Assessment of the uniformity of wheat and tomato varieties at DNA microsatellite loci. Euphytica 132 (3):331-341

Crespan M (2004) Evidence on the evolution of polymorphism of microsatellite markers in varieties of Vitis vinifera L. Theor Appl Genet 108 (2):231-237

Cretazzo E, Meneghetti S, De Andres MT, Gaforio L, Frare E, Cifre J (2010) Clone differentiation and varietal identification by means of SSR, AFLP, SAMPL and MAFLP in order to assess the clonal selection of grapevine: the case study of Manto Negro, Callet and Moll, autochthonous cultivars of Majorca. Ann Appl Biol 157 (2):213-227. doi:10.1111/j.1744-7348.2010.00420.x

Chomé P, Sotés V, Benayas F, Cayuela M, Hernández M, Cabello F, Ortiz J, RodríguezTorres I, Chaves J (2003) Variedades de vid. Registro de variedades comerciales. Centro de Publicaciones. Ministerio de Agricultura, Pesca y Alimentación, Madrid

Dalbó MA, Ye GN, Weeden NF, Steinkellner H, Sefc KM, Reisch BI (2000) A gene controlling sex in grapevines placed on a molecular marker-based genetic map. Genome 43:333-340

Franks TR, Botta R, Thomas MR, Franks J (2002) Chimerism in grapevines: implications for cultivar identity, ancestry and genetic improvement. Theor Appl Genet 104 (23):192-199

Galet P (2000) Dictionnaire Encyclopédique des Cépages. Hachette, Paris

Gonzalez Techera A, Jubany S, Ponce de Leon I, Boido E, Dellacassa E, Carrau FM, Hinrichsen P, Gaggero C (2004) Molecular diversity within clones of cv. Tannat (Vitis vinifera). Vitis 43 (4):179-185

Hidalgo L (1999) Tratado de Viticultura General. 2 edn. Mundi-Prensa, Madrid 
Hocquigny S, Pelsy F, Dumas V, Kindt S, Heloir MC, Merdinoglu D (2004)

Diversification within grapevine cultivars goes through chimeric states. Genome 47

(3):579-589

Ibáñez J, de Andrés MT, Borrego J (2000) Allelic variation observed at one microsatellite locus between the two synonym grape cultivars Black Currant and Mavri Corinthiaki. Vitis 39 (4):173-174

Ibáñez J, Vargas AM, Palancar M, Borrego J, de Andrés MT (2009a) Genetic relationships among table-grape varieties. Am J Enol Vitic 60 (1):35-42

Ibáñez J, Vélez M, de Andrés MT, Borrego J (2009b) Molecular markers for establishing distinctness in vegetatively propagated crops: a case study in grapevine. Theor Appl Genet 119 (7):1213-1222. doi:10.1007/s00122-009-1122-2

Imazio S, Labra M, Grassi F, Winfield M, Bardini M, Scienza A (2002) Molecular tools for clone identification: the case of the grapevine cultivar 'Traminer'. Plant Breeding $121(6): 531-535$

Kalia R, Rai M, Kalia S, Singh R, Dhawan A (2011) Microsatellite markers: an overview of the recent progress in plants. Euphytica 177 (3):309-334. doi:10.1007/s10681-010$0286-9$

Moncada X, Pelsy F, Merdinoglu D, Hinrichsen P (2006) Genetic diversity and geographical dispersal in grapevine clones revealed by microsatellite markers. Genome 49 (11):1459-1472

OIV (2007) 2nd edition of the OIV descriptor list for grape varieties and Vitis species.

Pelsy F (2010) Molecular and cellular mechanisms of diversity within grapevine varieties. Heredity 104 (4):331-340. doi:doi:10.1038/hdy.2009.161

Pelsy F, Hocquigny S, Moncada X, Barbeau G, Forget D, Hinrichsen P, Merdinoglu D (2010) An extensive study of the genetic diversity within seven French wine grape variety collections. Theor Appl Genet 120 (6):1219-1231

Regner F, Hack R, Santiago JL (2006) Highly variable Vitis microsatellite loci for the identification of Pinot Noir clones. Vitis 45 (2):85-91

Regner F, Stadlbauer A, Eisenheld C, Kaserer H (2000a) Genetic relationships among Pinots and related cultivars. Am J Enol Vitic 51 (1):7-14

Regner F, Wiedeck E, Stadlbauer A (2000b) Differentiation and identification of White Riesling clones by genetic markers. Vitis 39 (3):103-107

Riaz S, Garrison KE, Dangl GS, Boursiquot JM, Meredith CP (2002) Genetic divergence and chimerism within ancient asexually propagated winegrape cultivars. J Am Soc Hort Sci 127 (4):508-514

Sefc KM, Pejic I, Maletic E, Thomas MR, Lefort F (2009) Microsatellite markers for grapevine: tools for cultivar identification \& pedigree reconstruction. In: RoubelakisAngelakis KA (ed) Grapevine Molecular Physiology \& Biotechnology. 2nd edn. Springer, pp 565-596. doi:10.1007/978-90-481-2305-6_21

Sefc KM, Regner F, Turetschek E, Glössl J, Steinkellner H (1999) Identification of microsatellite sequences in Vitis riparia and their applicability for genotyping of different Vitis species. Genome 42:367-373

Tautz D (1989) Hypervariability of simple sequences as a general source for polymorphic DNA markers. Nucleic Acids Res 17 (16):6463-6471

This P, Lacombe T, Thomas MR (2006) Historical origins and genetic diversity of wine grapes. Trends Genet 22 (9):511-519. doi:10.1016/j.tig.2006.07.008 
Thomas MR, Scott NS (1993) Microsatellite repeats in grapevine reveal DNA polymorphisms when analysed as sequence-tagged sites (STSs). Theor Appl Genet 86:985-990

Thompson MM, Olmo HP (1963) Cytohistological studies of cytochimeric and tetraploid grapes. Am J Bot 50:901-906

UPOV (2002) General introduction to the examination of Distinctness, Uniformity and Stability and the development of harmonized descriptions of new varieties of plants. International Union for the Protection of New Varieties of Plants, Geneva

UPOV (2005) UPOV report on the impact of plant variety protection. International Union for the Protection of New Varieties of Plants, Geneva

UPOV (2008a) Examining Uniformity. International Union for the Protection of New Varieties of Plants, Geneva

UPOV (2008b) Grapevine: Guidelines for the conduct of tests for distinctness, uniformity and stability. International Union for the Protection of New Varieties of Plants, Geneva

UPOV (2009) Plant Variety Protection statistics for the period 2004-2008. International Union for the Protection of New Varieties of Plants, Geneva

Vargas AM, Velez MD, de Andres MT, Laucou V, Lacombe T, Boursiquot JM, Borrego J, Ibáñez J (2007) Corinto bianco: A seedless mutant of Pedro Ximenes. Am J Enol Vitic $58(4): 540-543$

Zulini L, Fabro E, Peterlunger E (2005) Characterisation of the grapevine cultivar Picolit by means of morphological descriptors and molecular markers. Vitis 44 (1):35-38

\section{Supporting Information}

Additional Supporting Information:

Supplementary Table S1. Summary of the plant material analyzed with the set of 9 microsatellites, classified by variety. For each microsatellite and variety, the total number of plants studied is shown.

Supplementary Table S2: List of alleles and their frequencies found in a non-redundant collection of 489 grapevine varieties for the nine microsatellites. In bold all the allelic frequencies above 0.04, as well as all the alleles found in the 19 varieties used in the study of uniformity and stability. 
Table 1. Some relevant characteristics of the 19 grapevine varieties selected for the assessment of uniformity and stability.

\begin{tabular}{|c|c|c|c|c|c|c|c|}
\hline Variety & $\begin{array}{c}\text { Country of } \\
\text { Origin }\end{array}$ & $\begin{array}{c}\text { Century } \\
\text { of Origin }\end{array}$ & Use $^{b}$ & Colour $^{c}$ & SDL $^{\mathrm{d}}$ & $\begin{array}{c}\text { Time of } \\
\text { ripening }\end{array}$ & $\begin{array}{c}\text { Cultivated } \\
\text { area }^{f}\end{array}$ \\
\hline Airén & Spain & 16 & $\mathrm{~W}$ & B & $\mathrm{N}$ & Very late & 476,000 \\
\hline Cabernet Sauvignon & France & 16 & $\mathrm{~W}$ & $\mathrm{~N}$ & $\mathrm{~N}$ & Medium-Late & 140,000 \\
\hline Cardinal & USA & 20 & $\mathrm{~T}$ & $\mathrm{R}$ & $\mathrm{N}$ & Early & 26,000 \\
\hline Chardonnay & France & 9 & W & B & $\mathrm{N}$ & Very early & 35,000 \\
\hline Crimson Seedless & USA & 20 & $\mathrm{~T}$ & $\mathrm{R}$ & $\mathrm{Y}$ & Medium-Late & nd \\
\hline Flame Seedless & USA & 20 & $\mathrm{~T}$ & $\mathrm{R}$ & $\mathrm{Y}$ & Early & nd \\
\hline Garnacha & Spain & 16 & $\mathrm{~W}$ & $\mathrm{~N}$ & $\mathrm{~N}$ & Medium & 419,000 \\
\hline Imperial Napoleón & Spain & 20 & $\mathrm{~T}$ & $\mathrm{~N}$ & $\mathrm{~N}$ & Late-Very late & $<5,000$ \\
\hline Italia & Italy & 20 & $\mathrm{~T}$ & B & $\mathrm{N}$ & Medium-Late & 20,000 \\
\hline Merlot & France & 19 & $\mathrm{~W}$ & $\mathrm{~N}$ & $\mathrm{~N}$ & Early-Medium & 145,000 \\
\hline Monastrell & Spain & 15 & $\mathrm{~W}$ & $\mathrm{~N}$ & $\mathrm{~N}$ & Very late & 120,000 \\
\hline Muscat of Alexandria & Africa & $1 \mathrm{BC}$ & $\mathrm{W}, \mathrm{T}$ & B & $\mathrm{N}$ & Late & 90,000 \\
\hline Ohanes & Spain & 18 & $\mathrm{~T}$ & B & $\mathrm{N}$ & Very late & 11,000 \\
\hline Palomino Fino & Spain & 16 & $\mathrm{~W}$ & B & $\mathrm{N}$ & Medium & 60,000 \\
\hline Red Globe & USA & 20 & $\mathrm{~T}$ & $\mathrm{R}$ & $\mathrm{N}$ & Medium-Late & nd \\
\hline Sauvignon Blanc & France & 16 & W & B & $\mathrm{N}$ & Early & 20,000 \\
\hline Sugraone & USA & 20 & $\mathrm{~T}$ & B & $\mathrm{Y}$ & Very Early & nd \\
\hline Sultanina ${ }^{c}$ & Afghanistan & & $\mathrm{T}$ & B & $\mathrm{Y}$ & Early & 350,000 \\
\hline Tempranillo & Spain & 18 & W & $\mathrm{N}$ & $\mathrm{N}$ & Early & 85,000 \\
\hline
\end{tabular}

${ }^{a}$ Century of the first citation found

${ }^{\mathrm{b}} \mathrm{W}$-wine; T-table

${ }^{\mathrm{c}} \mathrm{B}$-white (blanc); N-noir (black); R-rouge/rose (red/pink)

${ }^{\mathrm{d}}$ SDL-seedlessness; Y-yes; N-no

e According to (Chomé et al. 2003; Galet 2000)

f Approximated world hectares cultivated in 1990, according to (Hidalgo 1999); nd: not determined 
Table 2: Description of the sampling for 19 varieties and characteristics of the sampled material, including the number of wrong plots and plants determined after microsatellite analysis.

\begin{tabular}{|c|c|c|c|c|c|c|c|c|c|c|}
\hline Variety & $\mathbf{N}^{\mathbf{o}}$ U-plots ${ }^{\mathrm{a}}$ & $\begin{array}{l}\mathbf{N}^{\circ} \text { Plants } \\
\text { U-plots }\end{array}$ & $\mathbf{N}^{\mathbf{o}}$ S-plots ${ }^{\mathrm{b}}$ & $\begin{array}{l}\mathrm{N}^{0} \text { Plants } \\
\text { S-plots }\end{array}$ & Countries $^{c}$ & $\begin{array}{c}\text { Range for } \\
\text { planting year }\end{array}$ & $\begin{array}{c}\text { Difference between } \\
\text { extreme plot ages } \\
\text { (years) }\end{array}$ & $\begin{array}{l}\mathrm{N}^{\mathrm{o}} \text { wrong } \\
\text { U-plots }\end{array}$ & $\begin{array}{l}N^{0} \text { wrong } \\
\text { S-plots }\end{array}$ & $\begin{array}{l}\mathrm{N}^{\circ} \text { wrong } \\
\text { plants }\end{array}$ \\
\hline Airén & 3 & 156 & 7 & 49 & 6 & 1944-1990 & 46 & $2 \mathrm{P}$ & - & 14 \\
\hline Cabernet Sauvignon & 3 & 152 & 10 & 63 & $1,2,3,4,5,6,7$ & $1954-2001$ & 47 & - & - & 0 \\
\hline Cardinal & 3 & 156 & 10 & 57 & $2,4,6,7$ & $1949-2005$ & 56 & - & $1 \mathrm{C}$ & 5 \\
\hline Chardonnay & 3 & 154 & 9 & 59 & $1,2,3,4,5,6,7$ & $1952-2000$ & 48 & - & - & 0 \\
\hline Crimson Seedless & 3 & 156 & 12 & 77 & $1,5,6,7$ & 1994-2004 & 10 & - & - & 0 \\
\hline Flame Seedless & 2 & 72 & 9 & 59 & $1,6,7$ & 1976-1998 & 22 & - & - & 0 \\
\hline Garnacha & 4 & 208 & 9 & 67 & 6 & $1800-1999$ & 199 & $1 \mathrm{C}$ & - & 50 \\
\hline Imperial Napoleón & 3 & 158 & 9 & 58 & 6 & $1800-1997$ & 197 & - & - & 0 \\
\hline Italia & 3 & 158 & 8 & 51 & $1,4,6,7$ & $1990-2000$ & 10 & - & - & 0 \\
\hline Merlot & 4 & 208 & 9 & 58 & $1,2,3,5,6,7$ & $1956-2000$ & 44 & $1 \mathrm{C}$ & - & 50 \\
\hline Monastrell & 3 & 157 & 7 & 35 & 6 & 1800-1998 & 198 & $1 \mathrm{P}$ & $1 \mathrm{P}$ & 46 \\
\hline Muscat of Alexandria & 5 & 260 & 10 & 52 & $2,6,7$ & $1949-2001$ & 52 & $2 \mathrm{C}+1 \mathrm{P}$ & $1 \mathrm{C}+1 \mathrm{P}$ & 108 \\
\hline Ohanes & 3 & 158 & 8 & 52 & 2,6 & 1942-1995 & 53 & - & - & 0 \\
\hline Palomino Fino & 4 & 208 & 9 & 55 & 6 & 1914-1995 & 81 & $1 \mathrm{C}+2 \mathrm{P}$ & $1 \mathrm{C}$ & 64 \\
\hline Red Globe & 3 & 157 & 7 & 49 & 6 & $1994-2003$ & 9 & $1 \mathrm{P}$ & - & 6 \\
\hline Sauvignon Blanc & 3 & 156 & 7 & 42 & $1,2,3,4,5,6,7$ & $1954-2002$ & 48 & - & - & 0 \\
\hline Sugraone & 3 & 155 & 10 & 64 & $1,5,6$ & $1987-2000$ & 13 & - & - & 0 \\
\hline Sultanina & 2 & 88 & 12 & 68 & $1,5,6,7$ & $1800-1988$ & 203 & - & $2 \mathrm{C}$ & 10 \\
\hline Tempranillo & 3 & 156 & 7 & 49 & 6 & $1944-2000$ & 56 & $1 \mathrm{P}$ & - & 2 \\
\hline Total & 60 & 3,073 & 169 & 1,064 & & & & $5 C+8 P$ & $5 C+2 P$ & 355 \\
\hline
\end{tabular}

${ }^{a}$ U-Plots: plots where 52 samples were collected.

${ }^{\mathrm{b}}$ S-Plots: plots where 7 samples were collected.

c 1-Chile; 2-France; 3-Germany; 4-Hungary; 5-South Africa; 6-Spain; 7-USA

${ }^{\mathrm{d}} \mathrm{P}$ : Partial, only some plants of the plot were wrong; C: Complete, all the plants of the plot were wrong. 
Table 3: Genotypes of the 19 varieties studied for the 9 selected microsatellites.

\begin{tabular}{|c|c|c|c|c|c|c|c|c|c|c|c|c|c|c|c|c|c|c|}
\hline Variety & \multicolumn{2}{|c|}{ ZAG67 } & \multicolumn{2}{|c|}{ VVMD27 } & \multicolumn{2}{|c|}{ VVMD5 } & \multicolumn{2}{|c|}{ ZAG29 } & \multicolumn{2}{|c|}{ ZAG62 } & \multicolumn{2}{|c|}{ ZAG112 } & \multicolumn{2}{|c|}{ VVS2 } & \multicolumn{2}{|c|}{ ZAG83 } & \multicolumn{2}{|c|}{ VVMD28 } \\
\hline Airén & 129 & 147 & 178 & 191 & 222 & 231 & 109 & 109 & 187 & 199 & 227 & 232 & 140 & 142 & 192 & 195 & 232 & 242 \\
\hline abernet Sauvignon & 23 & & 73 & 86 & 27 & 237 & 109 & 09 & 187 & 93 & 227 & 232 & 36 & & 01 & 01 & 32 & \\
\hline & 23 & & & & 22 & & 109 & 9 & 185 & & 32 & 240 & 132 & & 190 & & 242 & \\
\hline & & & & & 31 & & 109 & 99 & 187 & & 38 & 238 & & & & & 16 & \\
\hline & & & & & 24 & & 109 & & 187 & & & & & & & & & \\
\hline & 123 & 137 & 78 & 182 & 31 & 233 & 109 & 111 & 187 & 187 & 240 & 40 & 130 & & 190 & 90 & 242 & \\
\hline Garı & 29 & 147 & & 19 & 22 & 237 & 109 & 109 & 187 & 187 & 227 & 227 & 134 & & 0 & 92 & 242 & \\
\hline & 37 & & 76 & 19 & 27 & 235 & 109 & 111 & 191 & 203 & 227 & 245 & 130 & & 0 & 195 & 232 & \\
\hline $\mathrm{Me}$ & 29 & 37 & 86 & 18 & 222 & 233 & 109 & 109 & 193 & 193 & 227 & 240 & 136 & 149 & 195 & 201 & 226 & \\
\hline & & & & & 22 & & 109 & 99 & 187 & 03 & 227 & 2 & 30 & & 2 & 01 & 42 & \\
\hline & & & & & 224 & 227 & 109 & & 185 & 203 & 232 & 45 & & & & & 242 & \\
\hline & 129 & & & 19 & 231 & 23 & 109 & 109 & 187 & 203 & 227 & 36 & 130 & & 201 & 201 & 242 & \\
\hline $\mathrm{Oh}$ & 129 & 137 & 180 & 191 & 231 & 233 & 109 & 109 & 199 & 203 & 236 & 238 & 130 & 34 & 190 & 201 & 242 & \\
\hline & 129 & 14 & 182 & 191 & 224 & 237 & 109 & 109 & 187 & 193 & 227 & 32 & 130 & 142 & 192 & 195 & 234 & \\
\hline & & & & 17 & 233 & & 109 & 109 & 185 & 187 & 227 & & 132 & & 19 & 201 & 256 & \\
\hline & & & & & 224 & & 109 & 113 & 187 & 193 & 232 & & 130 & & 19 & 201 & 232 & \\
\hline & & 137 & 176 & 178 & 222 & & 109 & & 185 & 187 & 232 & & 132 & & 190 & 195 & 246 & \\
\hline T & 123 & 147 & 180 & 180 & 233 & & 109 & 109 & 195 & 199 & 227 & & 140 & & 195 & 195 & 256 & \\
\hline Sultanina & 123 & 137 & 178 & 191 & 231 & 231 & 109 & 111 & 187 & 187 & 227 & 259 & 142 & 149 & 190 & 195 & 216 & 242 \\
\hline
\end{tabular}


Table 4: Extreme differences found for each microsatellite allele between all the plants within a variety. Each value represents the difference (in base pairs, bp) between the extreme raw values obtained for each allele/variety. The total number of values used in each case is shown in Supplementary Table S1. Absent values (-) appear for the second allele in homozygous genotypes (1 allelic value for a certain microsatellite). Differences larger than $1 \mathrm{bp}$ are highlighted.

\begin{tabular}{|c|c|c|c|c|c|c|c|c|c|c|c|c|c|c|c|c|c|c|c|}
\hline Variety & ZAG67 & ZAG67 & VVMD27 & VVMD27 & VVMD5 & VVMD5 & ZAG29 & ZAG29 & ZAG62 & ZAG62 & ZAG112 & ZAG112 & VVS2 & VVS2 & ZAG83 & ZAG83 & VVMD28 & VVMD28 & $\begin{array}{c}\text { Average } \\
\text { difference }\end{array}$ \\
\hline Airén & 0.7 & 0.38 & 0.41 & 0.63 & 0.5 & 0.7 & 0.91 & - & 0.8 & 0.4 & 0.47 & 0.45 & 0.54 & 0.53 & 0.51 & 0.43 & 0.74 & 0.75 & 0.58 \\
\hline Cabernet Sauvignon & 0.65 & 0.48 & 0.99 & 0.85 & 1.62 & 1.74 & 0.98 & - & 0.92 & 0.8 & 0.56 & 0.56 & 1.06 & 1.19 & 0.38 & - & 0.98 & 0.93 & 0.92 \\
\hline Cardinal & 0.54 & 0.4 & 0.71 & 0.99 & 0.79 & 0.83 & 0.88 & - & 0.99 & - & 0.7 & 0.67 & 0.85 & - & 0.47 & 0.5 & 0.98 & 0.99 & 0.75 \\
\hline Chardonnay & 0.56 & 0.62 & 0.57 & 0.57 & 0.68 & 0.58 & 0.57 & - & 0.63 & 0.58 & 0.51 & - & 0.63 & 0.67 & 0.36 & 0.51 & 0.68 & 0.77 & 0.59 \\
\hline Crimson Seedless & 0.53 & 0.42 & 0.77 & - & 0.91 & 0.88 & 0.89 & - & 0.62 & 0.64 & 0.48 & 0.63 & 0.94 & 0.9 & 0.47 & - & 0.63 & 0.63 & 0.69 \\
\hline Flame Seedless & 0.42 & 0.43 & 0.76 & 0.79 & 0.89 & 0.87 & 0.8 & 0.79 & 0.71 & - & 0.55 & - & 0.6 & 0.76 & 0.42 & - & 0.99 & - & 0.70 \\
\hline Garnacha & 0.56 & 0.57 & 0.98 & - & 0.94 & 0.96 & 0.94 & - & 0.94 & - & 0.71 & - & 0.74 & 0.77 & 0.7 & 0.72 & 0.88 & - & 0.80 \\
\hline Italia & 0.52 & 0.96 & 0.85 & 0.96 & 0.9 & 0.84 & 0.92 & 0.9 & 0.77 & 0.82 & 0.78 & 0.99 & 0.86 & 0.98 & 0.61 & 0.98 & 0.94 & 0.97 & 0.86 \\
\hline Merlot & 0.43 & 0.45 & 0.63 & 0.6 & 0.94 & 0.65 & 0.76 & - & 0.6 & - & 0.69 & 0.76 & 0.49 & 0.67 & 0.28 & 0.22 & 0.78 & 0.8 & 0.61 \\
\hline Monastrell & 0.49 & - & 0.66 & 0.59 & 0.74 & 0.81 & 0.78 & - & 0.67 & 0.7 & 0.5 & 0.48 & 0.65 & 0.8 & 0.34 & 0.37 & 0.86 & 0.83 & 0.64 \\
\hline Muscat of Alexandria & 0.42 & - & 0.68 & 0.77 & 0.68 & 0.63 & 0.8 & - & 0.88 & 0.56 & 0.41 & 0.53 & 0.98 & 0.74 & 0.56 & - & 0.64 & 0.71 & 0.67 \\
\hline Imperial Napoleón & 0.49 & 0.43 & 0.98 & 0.59 & 0.69 & 0.74 & 0.99 & - & 0.85 & 0.43 & 0.52 & 0.58 & 0.62 & 0.66 & 0.32 & - & 0.73 & 0.84 & 0.65 \\
\hline Ohanes & 0.39 & 0.27 & 0.78 & 0.76 & 0.54 & 0.48 & 0.73 & - & 0.43 & 0.61 & 0.4 & 0.35 & 0.72 & 0.68 & 0.56 & 0.53 & 0.7 & 0.9 & 0.58 \\
\hline Palomino Fino & 0.83 & 0.49 & 0.87 & 0.86 & 0.84 & 0.96 & 0.78 & - & 0.63 & 0.53 & 0.76 & 0.88 & 0.82 & 0.79 & 0.38 & 0.31 & 0.64 & 0.99 & 0.73 \\
\hline Red Globe & 0.78 & 0.44 & 0.99 & - & 1.25 & 1.4 & 0.99 & - & 0.97 & 0.95 & 0.82 & 0.83 & 0.88 & 1.07 & 0.69 & 0.46 & 1.35 & - & 0.92 \\
\hline Sauvignon Blanc & 0.54 & 0.41 & 0.74 & 0.64 & 0.83 & 0.8 & 0.98 & 0.75 & 0.63 & 0.58 & 0.56 & 0.61 & 0.81 & 0.91 & 0.41 & 0.32 & 0.88 & 0.96 & 0.69 \\
\hline Sugraone & 0.3 & 0.3 & 0.47 & 0.51 & 0.47 & 0.9 & 0.67 & 0.61 & 0.48 & 0.5 & 0.82 & - & 0.46 & - & 0.41 & 0.28 & 0.96 & - & 0.54 \\
\hline Sultanina & 0.55 & 0.51 & 0.94 & 0.84 & 0.98 & - & 0.8 & 0.76 & 0.98 & & 0.68 & 0.89 & 0.89 & 1 & 0.6 & 0.55 & 1.11 & 0.97 & 0.82 \\
\hline Tempranillo & 0.64 & 0.53 & 0.59 & - & 0.84 & - & 0.98 & - & 0.72 & 0.47 & 0.39 & 0.53 & 0.89 & 0.77 & 0.33 & - & 0.75 & - & 0.65 \\
\hline Average difference & \multicolumn{2}{|c|}{0.51} & \multicolumn{2}{|c|}{0.74} & \multicolumn{2}{|c|}{0.86} & \multicolumn{2}{|c|}{0.83} & \multicolumn{2}{|c|}{0.69} & \multicolumn{2}{|c|}{0.62} & \multicolumn{2}{|c|}{0.79} & \multicolumn{2}{|c|}{0.47} & \multicolumn{2}{|c|}{0.86} & 0.71 \\
\hline
\end{tabular}


Table 5: Results obtained for the nine variety $\mathrm{x}$ allele combinations where the differences between the maximum and minimum allele values were above $1 \mathrm{bp}$. The extreme differences obtained in two amplifications done in the same conditions (Taq polymerase) are shown. For 'Cabernet Sauvignon' other amplification was done with a proof-reading polymerase (Pyrobest DNA polymerase).

\begin{tabular}{|c|c|c|c|c|c|c|c|c|c|c|}
\hline \multirow[t]{2}{*}{ Variety } & \multirow[t]{2}{*}{ SSR(Allele) } & \multicolumn{3}{|c|}{$\begin{array}{l}\text { Taq polymerase } \\
\text { (1st amplification) }\end{array}$} & \multicolumn{3}{|c|}{$\begin{array}{c}\text { Taq polymerase } \\
\text { (2nd amplification) }\end{array}$} & \multicolumn{3}{|c|}{ Pyrobest DNA polymerase } \\
\hline & & Maximum & Minimum & Difference & Maximum & Minimum & Difference & Maximum & Minimum & Difference \\
\hline \multirow{4}{*}{ Cabernet Sauvignon } & VVMD5(1) & 228.90 & 227.28 & 1.62 & 228.56 & 228.57 & 0.01 & 227.61 & 227.63 & 0.02 \\
\hline & VVMD5(2) & 237.15 & 235.41 & 1.74 & 236.78 & 236.82 & 0.04 & 235.85 & 235.88 & 0.03 \\
\hline & VVS2(1) & 136.53 & 135.47 & 1.06 & 135.73 & 135.64 & 0.09 & 134.75 & 134.76 & 0.01 \\
\hline & VVS2(2) & 149.76 & 148.57 & 1.19 & 148.98 & 149.13 & 0.15 & 147.81 & 147.95 & 0.14 \\
\hline \multirow{4}{*}{ Red Globe } & VVMD5(1) & 233.87 & 232.62 & 1.25 & 232.75 & 232.60 & 0.15 & - & - & - \\
\hline & VVMD5(2) & 236.20 & 234.80 & 1.40 & 234.89 & 234.81 & 0.08 & - & - & - \\
\hline & VVS2(2) & 150.19 & 149.12 & 1.07 & 149.12 & 148.95 & 0.17 & - & - & - \\
\hline & VVMD28(1) & 257.42 & 256.07 & 1.35 & 256.19 & 256.06 & 0.13 & - & - & - \\
\hline Sultanina & VVMD28(1) & 217.49 & 216.38 & 1.11 & 216.45 & 216.33 & 0.12 & - & - & - \\
\hline
\end{tabular}


Figure 1: Representative normal (two-allele) and anomalous (three-allele) DNA profiles found for microsatellite VVMD27 in 'Merlot' (top) and for VVMD5 in 'Cardinal' (bottom). Microsatellite ssrVrZAG47 is the same locus than VVMD27 but with a different primer design (middle). 
Supplementary Table S1. Summary of the plant material analyzed with the 9 microsatellites, classified by variety. For each variety and microsatellite, the total number of plants studied is shown.

\begin{tabular}{|c|c|c|c|c|c|c|c|c|c|c|c|c|c|c|c|}
\hline Variety & $\begin{array}{c}\mathrm{N}^{\circ} \\
\text { U- } \\
\text { Plots }\end{array}$ & $\begin{array}{c}N^{\circ} \\
\text { Plants } \\
\text { U-plots }\end{array}$ & $\begin{array}{c}\text { No }^{\circ} \\
\text { S- } \\
\text { Plots }\end{array}$ & $\begin{array}{c}\mathrm{N}^{\mathbf{0}} \\
\text { Plants } \\
\text { S- } \\
\text { Plots }\end{array}$ & $\begin{array}{c}\mathrm{N}^{\circ} \\
\text { analyzed } \\
\text { plants }\end{array}$ & $\begin{array}{c}\mathrm{N}^{\circ} \\
\text { correct } \\
\text { plants }\end{array}$ & ZAG67 & VVMD27 & VVMD5 & ZAG29 & ZAG62 & ZAG112 & VVS2 & ZAG83 & VVMD28 \\
\hline Airén & 3 & 150 & 7 & 35 & 185 & 171 & 165 & 158 & 161 & 168 & 162 & 163 & 167 & 166 & 130 \\
\hline $\begin{array}{c}\text { Cabernet } \\
\text { Sauvignon }\end{array}$ & 3 & 150 & 7 & 35 & 185 & 185 & 185 & 185 & 185 & 185 & 185 & 185 & 185 & 185 & 185 \\
\hline Cardinal & 3 & 150 & 9 & 46 & 196 & 191 & 185 & 180 & 188 & 191 & 191 & 191 & 191 & 191 & 180 \\
\hline Chardonnay & 3 & 150 & 7 & 35 & 185 & 185 & 185 & 185 & 185 & 185 & 185 & 185 & 185 & 185 & 185 \\
\hline Flame Seedless & 2 & 70 & 9 & 42 & 112 & 112 & 110 & 112 & 110 & 112 & 111 & 112 & 110 & 112 & 111 \\
\hline Garnacha & 4 & 199 & 7 & 48 & 247 & 197 & 197 & 197 & 197 & 197 & 197 & 197 & 197 & 197 & 196 \\
\hline $\begin{array}{c}\text { Imperial } \\
\text { Napoleón }\end{array}$ & 3 & 150 & 9 & 42 & 192 & 192 & 192 & 192 & 192 & 192 & 192 & 192 & 192 & 192 & 192 \\
\hline Italia & 3 & 150 & 7 & 34 & 184 & 184 & 175 & 173 & 160 & 179 & 175 & 176 & 176 & 179 & 155 \\
\hline Merlot & 4 & 200 & 7 & 39 & 239 & 189 & 187 & 138 & 187 & 187 & 187 & 187 & 187 & 187 & 187 \\
\hline Monastrell & 3 & 150 & 7 & 27 & 177 & 131 & 131 & 131 & 131 & 131 & 131 & 131 & 131 & 131 & 131 \\
\hline Ohanes & 3 & 150 & 8 & 38 & 188 & 188 & 188 & 188 & 188 & 188 & 188 & 188 & 188 & 188 & 188 \\
\hline Palomino Fino & 4 & 200 & 8 & 40 & 240 & 176 & 176 & 176 & 176 & 176 & 176 & 176 & 176 & 176 & 176 \\
\hline Red Globe & 3 & 152 & 7 & 35 & 187 & 181 & 181 & 181 & 181 & 181 & 181 & 181 & 181 & 181 & 181 \\
\hline Sauvignon Blanc & 3 & 150 & 7 & 32 & 182 & 182 & 182 & 182 & 182 & 182 & 182 & 182 & 182 & 182 & 182 \\
\hline Sugraone & 3 & 150 & 7 & 35 & 185 & 185 & 185 & 185 & 185 & 185 & 185 & 185 & 185 & 185 & 185 \\
\hline Sultanina & 2 & 88 & 11 & 54 & 142 & 132 & 132 & 132 & 132 & 132 & 132 & 131 & 132 & 132 & 132 \\
\hline Tempranillo & 3 & 150 & 7 & 35 & 185 & 183 & 183 & 183 & 183 & 183 & 183 & 183 & 183 & 183 & 183 \\
\hline Total & 59 & 2,909 & 148 & 745 & 3,654 & 3,299 & 3,270 & 3,211 & 3,256 & 3,287 & 3,276 & 3,278 & 3,281 & 3,285 & 3,212 \\
\hline Average & 3.10 & 153.10 & 7.79 & 39.21 & 192.32 & 173.63 & 172.11 & 169.00 & 171.37 & 173.00 & 172.42 & 172.53 & 172.68 & 172.89 & 169.05 \\
\hline
\end{tabular}


Supplementary Table S2: List of alleles and their frequencies found in a non-redundant collection of 489 grapevine varieties for the nine microsatellites. In bold all the allelic frequencies above 0.04, as well as all the alleles found in the 19 varieties used in the study of uniformity and stability.

\begin{tabular}{|c|c|c|c|c|c|c|c|c|c|c|c|c|c|c|c|c|c|c|}
\hline \multirow{2}{*}{$\mathbf{N}^{\circ}$} & \multicolumn{2}{|c|}{ ZAG67 } & \multicolumn{2}{|c|}{ VVMD27 } & \multicolumn{2}{|c|}{ VVMD5 } & \multicolumn{2}{|c|}{ ZAG29 } & \multicolumn{2}{|c|}{ ZAG62 } & \multicolumn{2}{|c|}{ ZAG112 } & \multicolumn{2}{|c|}{ VVS2 } & \multicolumn{2}{|c|}{ ZAG83 } & \multicolumn{2}{|c|}{ VVMD28 } \\
\hline & Allele & Freq. & Allele & Freq. & Allele & Freq. & Allele & Freq. & Allele & Freq. & Allele & Freq. & Allele & Freq. & Allele & Freq. & Allele & Freq. \\
\hline 1 & 120 & 0.0010 & 166 & 0.0010 & 219 & 0.0164 & 107 & 0.0010 & 173 & 0.0010 & 227 & 0.2883 & 120 & 0.0020 & 159 & 0.0031 & 214 & 0.0041 \\
\hline 2 & 123 & 0.2515 & 173 & 0.0092 & 221 & 0.0010 & 109 & 0.7812 & 175 & 0.0020 & 229 & 0.0286 & 122 & 0.0061 & 161 & 0.0051 & 216 & 0.0409 \\
\hline 3 & 129 & 0.1380 & 176 & 0.1738 & 222 & 0.1616 & 111 & 0.0930 & 181 & 0.0112 & 232 & 0.2505 & 124 & 0.0010 & 166 & 0.0031 & 218 & 0.0041 \\
\hline 4 & 131 & 0.0031 & 178 & 0.1564 & 224 & 0.1094 & 113 & 0.0746 & 183 & 0.0010 & 234 & 0.0184 & 125 & 0.0010 & 172 & 0.0010 & 224 & 0.0072 \\
\hline 5 & 135 & 0.0031 & 180 & 0.0685 & 226 & 0.0031 & 115 & 0.0082 & 185 & 0.1155 & 236 & 0.0757 & 126 & 0.0010 & 174 & 0.0061 & 226 & 0.0348 \\
\hline 6 & 137 & 0.2474 & 182 & 0.1912 & 227 & 0.1258 & 117 & 0.0072 & 187 & 0.3282 & 238 & 0.1258 & 128 & 0.0031 & 176 & 0.0010 & 228 & 0.0041 \\
\hline 7 & 139 & 0.0092 & 184 & 0.0072 & 231 & 0.1125 & 119 & 0.0112 & 189 & 0.0092 & 240 & 0.1135 & 130 & 0.2618 & 184 & 0.0020 & 230 & 0.0010 \\
\hline 8 & 141 & 0.0112 & 186 & 0.1339 & 233 & 0.1708 & 121 & 0.0010 & 191 & 0.0501 & 243 & 0.0010 & 132 & 0.1176 & 185 & 0.0092 & 232 & 0.1391 \\
\hline 9 & 143 & 0.0031 & 188 & 0.0123 & 235 & 0.1401 & 123 & 0.0031 & 193 & 0.1186 & 245 & 0.0593 & 134 & 0.0859 & 188 & 0.0225 & 234 & 0.1094 \\
\hline 10 & 145 & 0.0082 & 191 & 0.2065 & 237 & 0.1002 & 125 & 0.0020 & 195 & 0.0736 & 247 & 0.0092 & 136 & 0.0174 & 190 & 0.2515 & 237 & 0.0092 \\
\hline 11 & 147 & & 192 & & 241 & & 129 & & 197 & 0.0041 & 249 & & 138 & 0.0112 & 192 & & 240 & 0.0072 \\
\hline 12 & 149 & 0.0491 & 194 & 0.0010 & 243 & 0.0184 & 131 & 0.0010 & 199 & 0.0481 & 251 & 0.0010 & 140 & 0.1411 & 195 & 0.3211 & 242 & 0.2198 \\
\hline 13 & 151 & 0.0337 & 196 & 0.0020 & 246 & 0.0051 & 133 & 0.0051 & 201 & 0.0286 & 253 & 0.0051 & 142 & 0.1166 & 201 & 0.1810 & 244 & 0.0378 \\
\hline 14 & 153 & 0.0941 & 198 & 0.0031 & 248 & 0.0061 & 135 & 0.0010 & 203 & 0.1922 & 255 & 0.0010 & 145 & 0.0133 & 207 & 0.0010 & 246 & 0.0920 \\
\hline 15 & 155 & 0.0174 & 200 & 0.0051 & 252 & 0.0010 & 139 & 0.0020 & 205 & 0.0041 & 259 & 0.0164 & 147 & 0.0552 & 217 & 0.0031 & 248 & 0.0041 \\
\hline 16 & 158 & 0.0184 & 202 & 0.0051 & 258 & 0.0010 & & & 209 & 0.0020 & 277 & 0.0010 & 149 & 0.1145 & & & 250 & 0.0092 \\
\hline 17 & 160 & 0.0031 & 204 & 0.0072 & 260 & 0.0092 & & & 213 & 0.0061 & & & 151 & 0.0072 & & & 252 & 0.0112 \\
\hline 18 & 162 & 0.0092 & 206 & 0.0041 & 262 & 0.0092 & & & 219 & 0.0041 & & & 153 & 0.0245 & & & 256 & 0.1769 \\
\hline 19 & 166 & 0.0010 & 208 & 0.0061 & 264 & 0.0061 & & & & & & & 156 & 0.0153 & & & 258 & 0.0297 \\
\hline 20 & 168 & 0.0010 & 211 & 0.0010 & & & & & & & & & 158 & 0.0020 & & & 260 & 0.0010 \\
\hline 21 & 170 & 0.0031 & 213 & 0.0031 & & & & & & & & & 160 & 0.0020 & & & 262 & 0.0061 \\
\hline 22 & 176 & 0.0061 & 215 & 0.0010 & & & & & & & & & & & & & 266 & 0.0501 \\
\hline 23 & & & & & & & & & & & & & & & & & 282 & 0.0010 \\
\hline
\end{tabular}




\begin{tabular}{lllllllllllll}
168 & 170 & 172 & 174 & 176 & 178 & 180 & 182 & 184 & 186 & 188 & 190 & 192 \\
\hline
\end{tabular}

VVMD27- 'Merlot' Normal profile

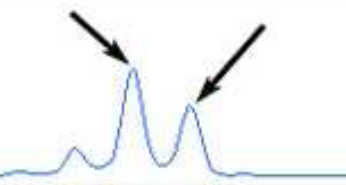

VVMD27- 'Merlot' Anomalous profile

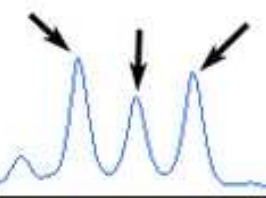

\begin{tabular}{lllllllllllll}
148 & 150 & 152 & 154 & 156 & 158 & 160 & 162 & 164 & 166 & 168 & 170 & 172 \\
\hline
\end{tabular} ssrVrZAG47- 'Merlot' Normal profile

ssrVrZAG47- 'Merlot' Anomalous profile

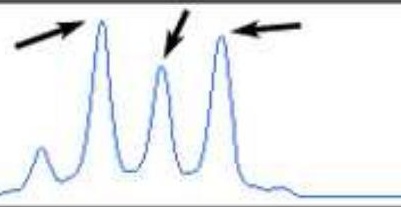

\begin{tabular}{lllllllllllll}
210 & 212 & 214 & 216 & 218 & 220 & 222 & 224 & 226 & 228 & 230 & 232 & 234 \\
\hline
\end{tabular}

VVMD5- 'Cardinal' Normal profile

VVMD5- 'Cardinal' Anomalous profile
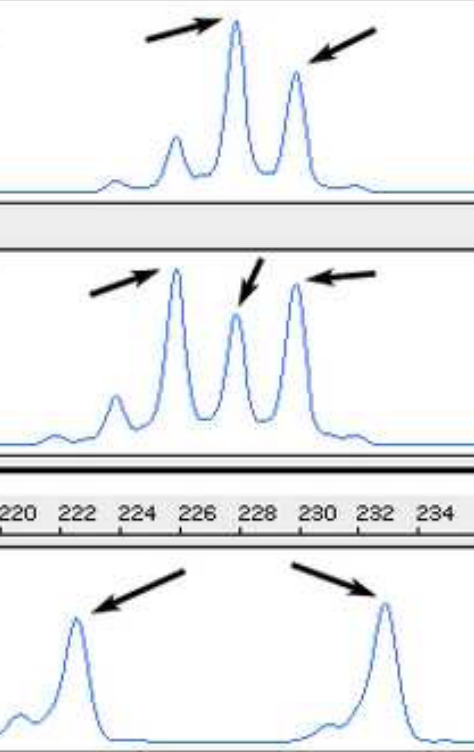